\title{
Inhibitors of Poliovirus Uncoating Efficiently Block the Early Membrane Permeabilization Induced by Virus Particles
}

\author{
MARÍA JESÚS ALMELA, MARÍA EUGENIA GONZÁLEZ, AND LUIS CARRASCO* \\ Centro de Biología Molecular, UAM-CSIC, Universidad Autónoma, Canto Blanco, 28049 Madrid, Spain
}

Received 6 September 1990/Accepted 18 January 1991

\begin{abstract}
The entry of animal viruses into cells is associated with permeabilization of the infected cells to protein toxins such as alpha-sarcin (C. Fernández-Puentes and L. Carrasco, Cell 20:769-775, 1980). This phenomenon has been referred to as "the early permeabilization by animal viruses"' (L. Carrasco, Virology 113:623-629, 1981). A number of inhibitors of poliovirus growth such as WIN 51711 6-(3,4-dichlorophenoxy)-3-(ethylthio)-2pyridincarbonitrile (DEPC) and Ro 09-0410 specifically block the uncoating step of poliovirus but have no effect on attachment or entry of poliovirus particles into cells. These agents are potent inhibitors of the early permeabilization induced by poliovirus to the toxin alpha-sarcin. Thus, the uncoating of poliovirus is required for the permeabilization of cell membranes to proteins. The increased entry of labeled heparin promoted by virus entry is not blocked by these agents, indicating that poliovirus binds to its receptor and is internalized along with heparin in endosomes in the presence of WIN 51711, DEPC, or Ro 09-0410. We conclude that the delivery to the cytoplasm of some molecules that coenter with virion particles does not take place if the uncoating process is hindered.
\end{abstract}

The infection of animal cells by viruses is initiated by the viral recognition of specific cellular receptors (8). After attachment, the virus enters the cell, usually by an endocytotic process (22), in a manner similar to that used by other biological molecules such as hormones or growth factors (17). Once the virus has been internalized within the cell, the virus must escape the endocytotic vesicle to locate its genome either in the cytoplasm or in the nucleus $(7,11)$. For enveloped viruses, the viral genome is released from endosomes by fusion of the viral membrane with the endosomal membrane $(7,22)$. Much less is known about the processes employed by nonenveloped viruses such as poliovirus in traversing the membrane barrier of the endosome in order to liberate the genomic RNA into the cytoplasm $(6,7,22)$.

A number of agents that inhibit picornavirus replication bind to virion particles, preventing virus uncoating without affecting the attachment of virions to cells or their internalization $(10,29)$. The detailed knowledge of some picornavirus particles at the atomic level $(1,23,26,30)$ allowed some researchers to carry out very refined studies on the interaction of WIN compounds with human rhinovirus 14 particles $(2,31,34)$. These are synthetic compounds that bind to a hydrophobic pocket located within VP1 and below the floor of the 'canyon,' a deep surface depression present in these particles $(2,31,34)$. This leads to a conformational change in the residues lining the canyon in human rhinovirus type 14 , thus inhibiting attachment in some rhinoviruses (27). The filling of this space by the WIN compounds within the pocket also enhances protein stability and in turn inhibits uncoating in all rhinovirus particles $(2,31,34)$.

Several years ago, we found that animal viruses, enveloped or naked, efficiently promoted the entry of proteins into infected cells along with the virions themselves $(4,5,13)$. Several protein toxins, including alpha-sarcin (13), enzymes, e.g., luciferase and horseradish peroxidase (28), and other low-molecular-weight inhibitors, e.g., hygromycin B (4), can enter cells together with virion particles and are then liber-

\footnotetext{
* Corresponding author
}

ated into the cytoplasm (6). No viral gene expression was required for this early membrane permeabilization to occur, indicating that the virion particles themselves were sufficient to promote this increased permeability (13). Even UVinactivated virions showed this effect $(4,5)$. These findings led us to suggest that virions lyse endosomes, thereby delivering the entrapped molecules into the cytoplasm (6). Electron microscopy studies on the permeabilization of cells to Pseudomonas toxin caused by adenovirions also favored this hypothesis (14). Direct early permeabilization of the plasma membrane by adenoviruses is also achieved if the culture medium is acidified, indicating that the low $\mathrm{pH}$ present in endosomes, together with virion particles might trigger the disruption of the endosomal membrane by naked viruses (32). As yet, no selective inhibitors of this early membrane modification induced by animal viruses are known. We now describe how compounds that block poliovirus uncoating, such as WIN $51711(15,29)$, 6-(3,4-dichlorophenoxy)-3-(ethylthio)-2-pyridincarbonitrile (DEPC) (18), and Ro 09-0410 (24) interfere with early permeabilization of cell membranes, suggesting that this phenomenon is tightly coupled to virion uncoating.

\section{MATERIALS AND METHODS}

Cells and viruses. Human HeLa cells were grown in Dulbecco modified Eagle medium supplemented with $10 \%$ newborn calf serum and containing antibiotics $(10,000 \mathrm{IU}$ of penicillin and $50 \mathrm{mg}$ of streptomycin per $\mathrm{ml}$ ). Poliovirus type 1 (Mahoney strain) was grown on HeLa cells. The virus concentration was estimated by plaque assays on the same cell line.

Source of compounds. DEPC was a generous gift from M. T. Kenny (Merrell Dow Research Institute, Indianapolis, Ind.). Ro 09-0410 (4'-ethoxy-2'-hydroxy-4,6'-dimethoxychalcone) and Ro 09-0179 (4',5-dihydroxy-3-3'-7-trimethoxyflavone) were kindly given to us by $\mathrm{H}$. Ishitsuka and $\mathrm{K}$. Yokose (Nippon Roche Research Center, Kanagawa, Japan). WIN 51711 (5-[7-[4-[4,5-dihydro-2-oxazoly]phenoxy]heptyl]3-methylisoxazole) was generously provided by D. Pevear 
(Sterling Research Group, Rensselaer, N.Y.). Rhodanine (2-thioxo-4-thiazolidinone), guanidine hydrochloride, gliotoxin, and dactinomycin were purchased from Sigma Chemical Co., St. Louis, Mo. Alpha-sarcin, a toxic protein (molecular weight, 16,800) produced by Aspergillus giganteus, was given to us by D. M. Schuurmans (Department of Public Health, Lansing, Mich.), and hygromycin B (molecular weight, 527), produced by Streptomyces hygroscopicus, was obtained from Lilly Research Laboratories (Indianapolis, Ind.).

Measurement of protein synthesis. Methionine-free medium $\left(0.2 \mathrm{ml}\right.$ per well) containing $0.2 \mathrm{mCi}$ of $\left[{ }^{35} \mathrm{~S}\right]$ methionine $(1,100 \mathrm{Ci} / \mathrm{mmol})$ from the Radiochemical Centre (Amersham, England) was added to cells grown on 24-well dishes. The cell monolayer was incubated at $37^{\circ} \mathrm{C}$ for $1 \mathrm{~h}$, and the medium was then removed. Cells were fixed with $5 \%$ trichloroacetic acid (TCA) and washed with ethanol. The fixed cell monolayer was dried and resuspended in $0.2 \mathrm{ml}$ of $0.1 \mathrm{~N}$ $\mathrm{NaOH}-1 \%$ sodium dodecyl sulfate (SDS). The radioactivity was measured in a liquid scintillation counter (Intertecnique).

Radiolabeling and purification of poliovirus. HeLa cells were grown on 100-mm-diameter dishes. The cell monolayers were infected with poliovirus at a multiplicity of 5 PFU per cell in Dulbecco modified Eagle medium supplemented with $2 \%$ newborn calf serum. At $3 \mathrm{~h}$ postinfection, the cell monolayer was washed once with fresh methionine-free medium, and $3 \mathrm{ml}$ of this medium containing $40 \mathrm{mCi}$ of $\left[{ }^{35} \mathrm{~S}\right]$ methionine per dish was added. At $9 \mathrm{~h}$ postinfection, the cells were harvested and disrupted by freezing and thawing. The cellular extracts were centrifuged at $10,000 \mathrm{rpm}$ for 30 min in an SS-34 Sorvall rotor at $4^{\circ} \mathrm{C}$. The supernatants were layered onto $5 \mathrm{ml}$ of a $15 \%$ sucrose cushion $(50 \mathrm{mM} \mathrm{NaCl}, 10$ $\mathrm{mM}$ Tris $\mathrm{HCl}$ [pH 7.4]) and centrifuged at 38,000 rpm for $2 \mathrm{~h}$ at $4^{\circ} \mathrm{C}$ in a T-865 Sorvall rotor. Pellets were resuspended in $0.5 \mathrm{ml}$ of Dulbecco modified Eagle medium, and then Nonidet P-40 was added (1\% final concentration).

The virus solution was then centrifuged through a 15 to $45 \%$ linear sucrose gradient containing $50 \mathrm{mM} \mathrm{NaCl}$ and 10 $\mathrm{mM}$ Tris $\mathrm{HCl}(\mathrm{pH} \mathrm{7.4)}$ at $25,000 \mathrm{rpm}$ for $4 \mathrm{~h}$ in an $\mathrm{AH}-627$ Sorvall rotor at $4^{\circ} \mathrm{C}$. Each fraction contained $1.5 \mathrm{ml}$, of which $5 \mu$ l was used for determining the peak of radioactive virus. Selected fractions were pooled and centrifuged at $38,000 \mathrm{rpm}$ for $2 \mathrm{~h}$ in a T-865 rotor at $4^{\circ} \mathrm{C}$, and the pellet was resuspended in $0.5 \mathrm{ml}$ of Dulbecco modified Eagle medium.

HeLa cells were infected with $\left[{ }^{35} \mathrm{~S}\right]$ methionine-labeled poliovirus and incubated at $37^{\circ} \mathrm{C}$. Unattached virus was removed by washing with phosphate-buffered saline (PBS), and the cell monolayer was treated with $50 \mu \mathrm{g}$ of proteinase $\mathrm{K}$ per $\mathrm{ml}$ for $30 \mathrm{~min}$ at $4^{\circ} \mathrm{C}$. Cells were collected, washed with PBS, and precipitated with $10 \%$ TCA. The radioactivity retained on $\mathrm{GF} / \mathrm{C}$ filters was determined.

Measurement of poliovirus attachment to HeLa cells. HeLa cells grown on 35-mm-diameter dishes were precooled on ice for $15 \mathrm{~min}$ and then were infected with $\left[{ }^{35} \mathrm{~S}\right]$ methioninelabeled poliovirus and incubated at $4^{\circ} \mathrm{C}$. At various times, the cell monolayers were washed twice with ice-cold PBS to remove unbound virus and the cells were collected (all these processes were done at $4^{\circ} \mathrm{C}$ ). Cells were precipitated with $10 \%$ TCA, and the radioactivity retained on GF/C filters was measured.

Estimation of $\left[{ }^{3} \mathbf{H}\right]$ heparin uptake by $\mathrm{HeLa}$ cells. HeLa cell monolayers were incubated with $\left[{ }^{3} \mathrm{H}\right]$ heparin $(0.49 \mathrm{mCi} / \mathrm{mg}$; NEN Research Products, Du Pont de Nemours, Dreieich, Germany) in 24-well plates. At $2 \mathrm{~h}$ postinfection, the cells were fixed with 5\% TCA and then washed twice with
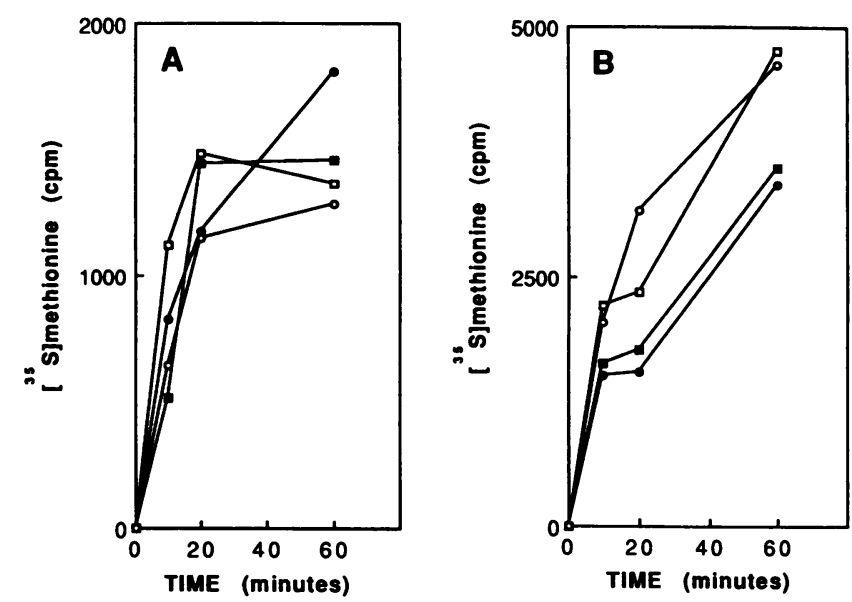

FIG. 1. (A) Effect of inhibitors on poliovirus attachment to HeLa cells. Cells were infected with $\left[{ }^{35} \mathrm{~S}\right]$ methionine-labeled poliovirus in the absence of inhibitor $(\square)$ or in the presence of $20 \mu \mathrm{g}$ of DEPC per $\mathrm{ml}(\square), 25 \mu \mathrm{g}$ of Ro 09-0410 per ml (O), or $10 \mu \mathrm{g}$ of WIN 51711 per $\mathrm{ml}(\mathrm{O})$ and incubated at $4^{\circ} \mathrm{C}$ as described in Materials and Methods. HeLa cells were harvested, and the TCA-precipitable radioactivity retained on GF/C filters was counted at selected times postinfection. (B) Effect of inhibitors on poliovirus entry into cells. HeLa cells were infected with $\left[{ }^{35} \mathrm{~S}\right]$ methionine-labeled poliovirus and incubated at $37^{\circ} \mathrm{C}$ in the absence or presence of the compounds described in panel $\mathrm{A}$. Cells were collected and treated with proteinase $\mathrm{K}$ at the indicated times as described in Materials and Methods. The TCAprecipitable radioactivity retained on $\mathrm{GF} / \mathrm{C}$ filters was measured.

ethanol. Dried precipitated cells were resuspended in $0.2 \mathrm{ml}$ of $0.1 \mathrm{~N} \mathrm{NaOH}-1 \%$ SDS, and the radioactivity was estimated in an Intertecnique liquid scintillation counter.

\section{RESULTS}

Attachment and entry of poliovirus in the presence of uncoating inhibitors. We measured the binding of $\left[{ }^{35} \mathrm{~S}\right] \mathrm{me}$ thionine-labeled poliovirus to $\mathrm{HeLa}$ cells at $4^{\circ} \mathrm{C}$ in the presence of WIN 51711, DEPC, and Ro 09-0410 to analyze the effect of these agents on poliovirus attachment and entry. Poliovirus attached to cells at control levels in the presence of any of the three inhibitors tested (Fig. 1A). The internalization of virus particles into $\mathrm{HeLa}$ cells at $37^{\circ} \mathrm{C}$ was not blocked by these inhibitors (Fig. 1B), indicating that these two early events are not the target of these compounds. This agrees with the findings that the uncoating process is the step blocked by these agents $(15,18,24)$.

Effect of WIN 51711, DEPC, and Ro 09-0410 on the simultaneous entry of alpha-sarcin and viral particles into cells. When virion particles enter cells, there is a parallel coentry of a number of enzymes and protein toxins that are in the culture medium $(4,6,13,14,28)$. Since protein synthesis is inhibited by these toxins, which have ribosomes as their target, this suggests that the toxins must be located in the cytoplasm $(6,14)$. The presence of alpha-sarcin together with poliovirus particles induced a profound and rapid blockade of protein synthesis (Fig. 2). Neither poliovirus particles nor alpha-sarcin alone were able to perform this inhibition. Strikingly, increasing concentrations of WIN 51711, DEPC, or Ro 09-0410 reversed this inhibition, suggesting that the toxin does not reach the cytoplasm when these uncoating inhibitors are present. This occurred even under high concentrations of alpha-sarcin (Fig. 3). 

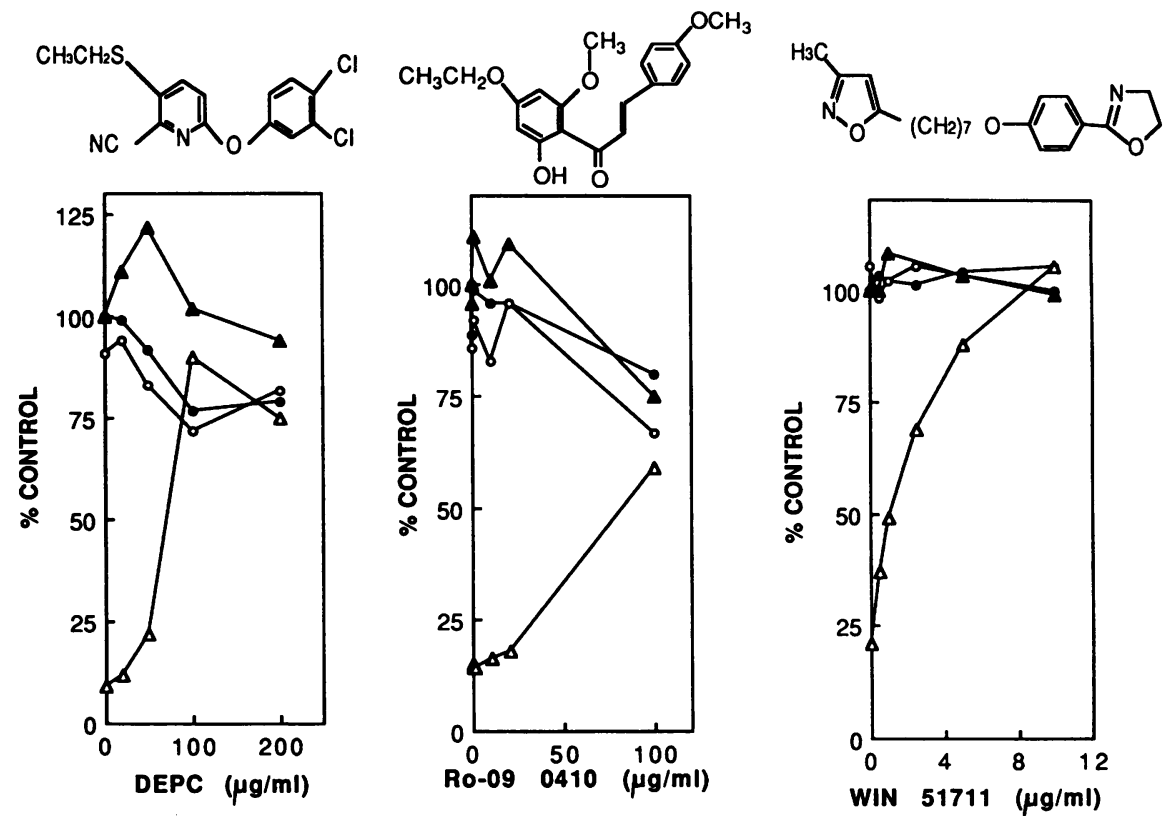

FIG. 2. Effect of different concentrations of the uncoating inhibitors on the early permeabilization. Cell monolayers were placed in methionine-free medium and mock infected or infected with poliovirus at a multiplicity of infection of 25 in presence or absence of $50 \mu \mathrm{g}$ of alpha-sarcin per ml under different concentrations of the inhibitory compounds DEPC, Ro 09-0410, and WIN 51711. At $1 \mathrm{~h}$ postinfection, protein synthesis was measured as described in Materials and Methods. Symbols: $\bullet$, uninfected cells; $\bigcirc$, uninfected cells plus alpha-sarcin; $\Delta$, poliovirus-infected cells; $\Delta$, poliovirus-infected cells plus alpha-sarcin.

We tested the effect of this phenomenon on other agents that block poliovirus growth by inhibiting poliovirus RNA synthesis, e.g., guanidine, gliotoxin, and Ro 09-0179, to analyze the selectivity of the inhibition of alpha-sarcin coentry with poliovirus. None of these compounds had any effect on the early permeabilization of cells to alpha-sarcin
(Table 1). The partial effect observed with Ro 09-0179 was mainly due to the inhibition observed with this compound in control cells. Rhodanine, a selective inhibitor of echovirus type 12 uncoating (12), and dactinomycin, an inhibitor of cellular but not viral RNA synthesis, were also devoid of effect (Table 1). A number of animal viruses including
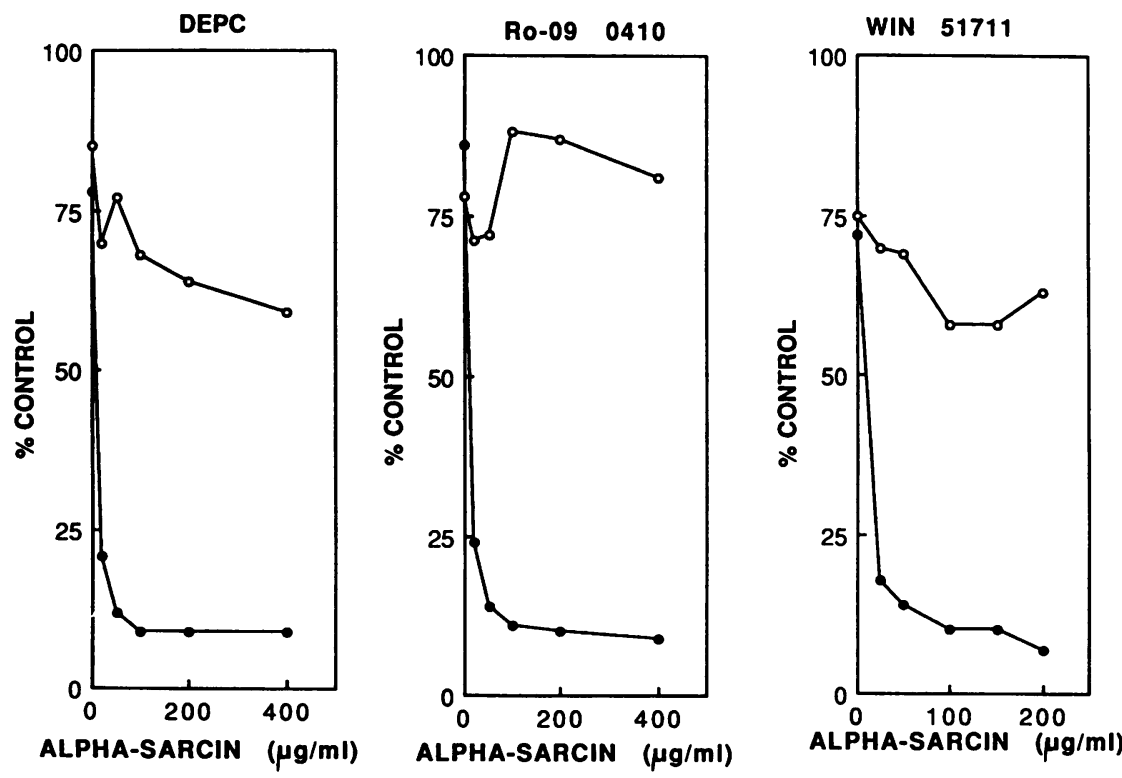

FIG. 3. Effect of uncoating inhibitors on the early membrane leakiness. HeLa cell monolayers were mock infected or infected with poliovirus at a multiplicity of infection of 25 PFU per cell in the absence or presence of $50 \mu \mathrm{g}$ of DEPC per ml, $100 \mu \mathrm{g}$ of Ro $09-0410 \mathrm{per} \mathrm{ml}$, or $10 \mu \mathrm{g}$ of WIN 51711 per ml. After $1 \mathrm{~h}$ of incubation at $37^{\circ} \mathrm{C}$, protein synthesis was estimated as described in Materials and Methods. Percentage of control is expressed as $\left[{ }^{35} \mathrm{~S}\right]$ methionine counts per minute in infected cells divided by the counts per minute in uninfected cells in the presence $(O)$ or absence $(O)$ of uncoating inhibitors. 
TABLE 1. Effect of a number of compounds on the early permeabilization induced by poliovirus infection ${ }^{a}$

\begin{tabular}{|c|c|c|c|}
\hline \multirow{2}{*}{ HeLa cells } & \multirow{2}{*}{ Compound } & \multicolumn{2}{|c|}{ Amt of $\left[{ }^{35} S\right]$ methionine incorporated (cpm) } \\
\hline & & Control & + Alpha-sarcin (\% of control) \\
\hline Uninfected & & 109,683 & $113,780(103)$ \\
\hline Poliovirus infected & & 84,007 & $22,183(26)$ \\
\hline Poliovirus infected & DEPC $(100 \mu \mathrm{g} / \mathrm{ml})$ & 52,894 & $57,774(109)$ \\
\hline Poliovirus infected & DEPC $(80 \mu \mathrm{g} / \mathrm{ml})$ & 60,246 & $62,951(104)$ \\
\hline Poliovirus infected & Ro $09-0410(150 \mu \mathrm{g} / \mathrm{ml})$ & 40,530 & $35,440(87)$ \\
\hline Poliovirus infected & Ro $09-0410(100 \mu \mathrm{g} / \mathrm{ml})$ & 52,233 & $50,971(98)$ \\
\hline Poliovirus infected & WIN $51711(10 \mu \mathrm{g} / \mathrm{ml})$ & 86,128 & $78,797(91)$ \\
\hline Poliovirus infected & Ro 09-0179 $(10 \mu \mathrm{g} / \mathrm{ml})$ & 50,622 & $26,979(53)$ \\
\hline Poliovirus infected & Rhodanine $(200 \mu \mathrm{g} / \mathrm{ml})$ & 83,602 & $18,635(22)$ \\
\hline Poliovirus infected & Guanidine $(3 \mathrm{mM})$ & 87,212 & $19,404(22)$ \\
\hline Poliovirus infected & Gliotoxin $(0.15 \mu \mathrm{g} / \mathrm{ml})$ & 87,689 & $21,287(24)$ \\
\hline Poliovirus infected & Dactinomycin $(5 \mu \mathrm{g} / \mathrm{ml})$ & 66,026 & $12,040(18)$ \\
\hline
\end{tabular}

${ }^{a}$ HeLa cells grown in 24-well culture dishes were mock infected or infected with poliovirus type 1 at a multiplicity of infection of 25 . The indicated compounds and $50 \mu \mathrm{g}$ of alpha-sarcin per $\mathrm{ml}$ were added as indicated to the methionine-free medium from the beginning of infection. At $1 \mathrm{~h}$ postinfection, proteins were labeled with $\left[{ }^{35}\right.$ S ]methionine for $1 \mathrm{~h}$, and the radioactivity incorporated was measured.

poliovirus permeabilize cells during the late phase of infection, the so-called "late membrane leakiness" (3). When inhibitors of poliovirus RNA replication were added early during infection but after poliovirus entry, they prevented the appearance of late membrane leakiness, measured by the entry of the nonpermeable inhibitor hygromycin B (Table 2). This effect did not occur when these agents were added $5 \mathrm{~h}$ postinfection. In fact, none of the antipicornavirus agents tested, including the uncoating inhibitors, were able to affect the late permeability to hygromycin $B$ when they were added $5 \mathrm{~h}$ postinfection (Table 2 ). These results indicate that active viral replication is required to fully permeabilize cells late during infection and suggest that the blockade of alphasarcin entry by uncoating inhibitors during the early permeabilization is very specific since these agents do not block late membrane permeability.

$\left[{ }^{3} \mathbf{H}\right]$ heparin entry during early stages of poliovirus infection. The experiments described in the previous section showed that the macromolecule alpha-sarcin does not reach the cytoplasm in the presence of uncoating inhibitors. However, it is not known whether these macromolecules can still coenter with virion particles into endosomes and whether the exit of alpha-sarcin from endosomes is the actual step blocked by WIN 51711, DEPC, and Ro 09-0410. We made use of radioactively labeled heparin to address this problem. Viruses not only promote the entry of proteins and other low-molecular-weight compounds into cells but also greatly enhanced the internalization of polysaccharides (19). The presence of poliovirus enhanced the uptake of heparin into HeLa cells threefold (Fig. 4). This increased entry was not modified by the uncoating inhibitors that we used.

All these findings fit well with the model depicted in Fig. 5, which suggests that viral particles are cointernalized with added compounds such as alpha-sarcin or heparin $(4,6,13$, 14). They would then pass to the cell interior through endosomes. The release of the viral genome into the cytoplasm (uncoating) or the exit of the cointernalized compounds would then be blocked by uncoating inhibitors. Thus, normal virus uncoating is required for the early permeabilization by viruses.

\section{DISCUSSION}

The mechanism(s) used by naked viruses to cross cellular membranes and deliver their genomes in the cytoplasm or the nucleus remains obscure $(1,2,4,6)$. An attractive possibility is that virion particles have devices to permeabilize endosomal membranes (6). This possibility would ex-

TABLE 2. Effect of several compounds on the late permeabilization induced by poliovirus infection ${ }^{a}$

\begin{tabular}{|c|c|c|c|c|c|}
\hline \multirow{3}{*}{ HeLa cells } & \multirow{3}{*}{ Compound } & \multicolumn{4}{|c|}{ Amt of $\left[{ }^{35}\right.$ S $]$ methionine incorporated $(\mathrm{cpm})$ when compound was added: } \\
\hline & & \multicolumn{2}{|r|}{$1 \mathrm{~h}$ postinfection } & \multicolumn{2}{|r|}{$5 \mathrm{~h}$ postinfection } \\
\hline & & Control & +Hygromycin B (\% of control) & Control & + Hygromycin B (\% of control) \\
\hline Uninfected & & 119,852 & $116,631(97)$ & 113,979 & $128,444(113)$ \\
\hline Poliovirus infected & & 30,605 & $4,831(16)$ & 22,073 & $5,174(23)$ \\
\hline Poliovirus infected & DEPC $(100 \mu \mathrm{g} / \mathrm{ml})$ & 12,059 & $7,120(59)$ & 12,182 & $2,565(21)$ \\
\hline Poliovirus infected & Ro $09-0410(150 \mu \mathrm{g} / \mathrm{ml})$ & 14,955 & $3,394(23)$ & 14,212 & $4,649(33)$ \\
\hline Poliovirus infected & Ro $09-0410(100 \mu \mathrm{g} / \mathrm{ml})$ & 17,775 & $6,309(35)$ & 25,044 & $4,935(20)$ \\
\hline Poliovirus infected & WIN $51711(10 \mu \mathrm{g} / \mathrm{ml})$ & 25,769 & $5,060(20)$ & 22,020 & $7,218(33)$ \\
\hline Poliovirus infected & Rhodanine $(200 \mu \mathrm{g} / \mathrm{ml})$ & 40,315 & 7,059 (17) & 23,731 & $4,245(18)$ \\
\hline Poliovirus infected & Ro 09-0179 $(10 \mu \mathrm{g} / \mathrm{ml})$ & 70,801 & $41,283(58)$ & 18,063 & $2,781(15)$ \\
\hline Poliovirus infected & Guanidine (3 $\mathrm{mM})$ & 113,454 & $105,130(93)$ & 23,574 & $4,157(18)$ \\
\hline Poliovirus infected & Gliotoxin $(0.15 \mu \mathrm{g} / \mathrm{ml})$ & 51,368 & $32,804(64)$ & 23,372 & $3,760(16)$ \\
\hline Poliovirus infected & Dactinomycin $(5 \mu \mathrm{g} / \mathrm{ml})$ & & & 22,286 & $4,862(22)$ \\
\hline
\end{tabular}

a HeLa cells were grown in 24-well dishes and mock infected or infected with poliovirus type 1 at a multiplicity of infection of 25 . Compounds were added to the medium at 1 or $5 \mathrm{~h}$ postinfection. In all cases, $1 \mathrm{mM}$ hygromycin B was added at $5 \mathrm{~h}$ postinfection, and 30 min later, protein synthesis was measured as described in Materials and Methods. 

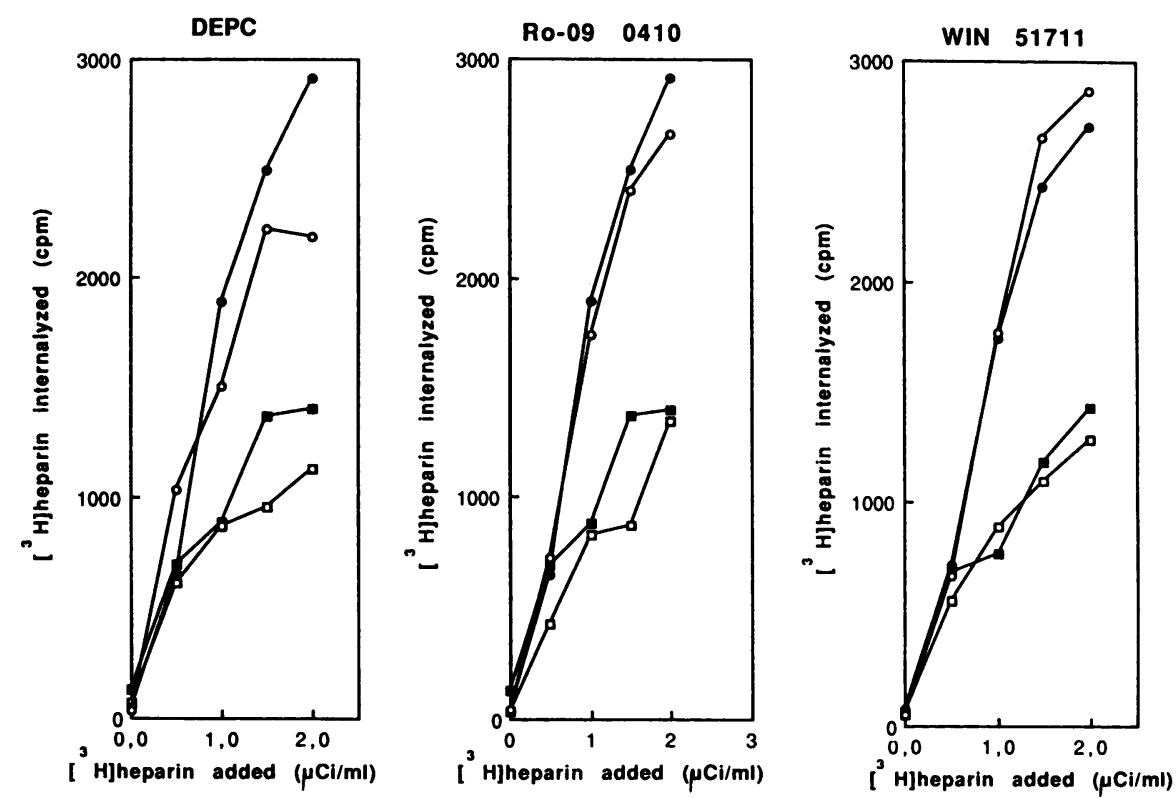

FIG. 4. Effect of uncoating inhibitors on $\left[{ }^{3} \mathrm{H}\right]$ heparin entry. Monolayers of HeLa cells were mock infected or infected with poliovirus type 1 at a multiplicity of infection of 50 PFU per cell in the absence or presence of DEPC $(25 \mu \mathrm{g} / \mathrm{ml})$, Ro 09-0410 $(100 \mu \mathrm{g} / \mathrm{ml})$, or WIN 51711 (1 $\mu \mathrm{g} / \mathrm{ml})$. Several concentrations of $\left[{ }^{3} \mathrm{H}\right]$ heparin were added. The radioactivity internalized into HeLa cells was counted after $2 \mathrm{~h}$ of incubation at $37^{\circ} \mathrm{C}$. Symbols: Uninfected cells with $(\square)$ or without $(\square)$ inhibitor; poliovirus-infected cells with $(O)$ or without $(\bullet)$ inhibitor.

plain why enveloped as well as naked viruses are able to permeabilize cell membranes to compounds present in the culture medium during early steps of virus infection (i.e., virus entry and uncoating) $(4,13)$. The entrance mechanism of these compounds into cells is probably their cointernalization with virions (14). Most probably, endosomes are later permeabilized by virions in a process that remains obscure. Our present findings indicate that this early permeabilization requires poliovirus uncoating. Thus, during uncoating, endosomes become permeabilized not only to the viral genome but also to other macromolecules entrapped inside them. Therefore, the uncoating process should be regarded as a series of well-defined events. After binding of poliovirus to its receptor, one or more virion proteins interact with the endosomal membrane. In fact, poliovirus protein VP4 is released in the membrane of the infected cells during the entry process and the amino terminus of VP1 is inserted into endosomal membranes (16). This mechanism may be similar to the interaction of the haptomer moiety of some protein toxins $(21,25)$, which promotes the entry of the effectomer moiety to the cytoplasm. In this regard, it is interesting to keep in mind that the haptomer molecule of these toxins can be replaced by virion particles (13), permitting effectors to pass to the cytoplasm in the presence of virions (13). Once the viral protein interacts with the endosomal membrane, it may become bound to it $(9,20)$. This event might trigger the

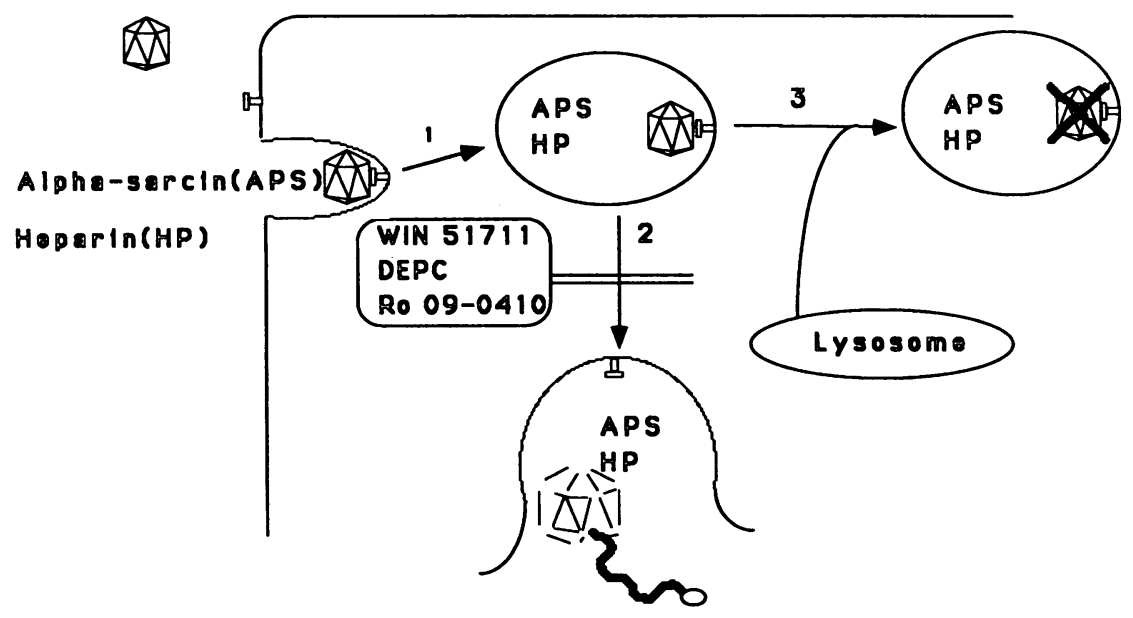

FIG. 5. Schematic representation of the mode of action of uncoating inhibitors. Alpha-sarcin or heparin when present in the culture medium is cointernalized with poliovirus particles in endosomes. Macromolecules are freed into the cytoplasm under normal conditions, but in the presence of uncoating inhibitors they are not liberated in the cytoplasm and follow the same fate as poliovirus particles. 
uncoating process by destabilizing virion particles. In turn, this may also increase membrane permeability (6). Thus, the uncoating step and the early membrane leakiness could be envisaged as coupled phenomena. When uncoating inhibitors are bound to virion particles filling the hydrophobic pocket $(26,28,30,33)$, they make some viral proteins more rigid, impeding the interaction of viral proteins with the endosomal membrane, a step needed for virus uncoating and membrane permeabilization.

The increased entry of polysaccharides combined with the coentry of protein toxins can be used as a convenient and easy test to identify uncoating inhibitors. Such compounds would not affect the increased entry of labeled polysaccharides, indicating that virus binding to the receptor and internalization are not blocked. However, such compounds would impede the inhibition of translation due to the presence of alpha-sarcin or similar toxins.

\section{ACKNOWLEDGMENTS}

We are indebted to M. G. Rossmann for the critical reading of this manuscript and to M. T. Kenny (Merrell Dow Research Institute), H. Ishitsuka and K. Yokose (Nippon Roche Research Center), and D. Pevear and M. A. McKinlay (Sterling Research Group) for the generous gifts of DEPC, Ro 09-0410, and WIN 51711, respectively. The technical assistance of $\mathbf{M}$. Chorro is acknowledged.

M.E.G. was the holder of an F.P.I. fellowship. Fundación Ramón Areces and CAICYT are acknowledged for financial support.

\section{REFERENCES}

1. Acharya, R., E. Fry, D. Stuart, G. Fox, D. Rowlands, and F. Brown. 1989. The three dimensional structure of foot-andmouth disease virus at $2.9 \AA$ resolution. Nature (London) 337:709-716.

2. Badger, J., I. Minor, M. J. Kremer, M. A. Oliveira, T. J. Smith, J. P. Griffith, D. M. A. Guerin, S. Krishnaswamy, M. Luo, M. G. Rossmann, M. A. McKinlay, G. D. Diana, F. J. Dutko, M. Fancher, R. R. Rueckert, and B. A. Heinz. 1988. Structural analysis of a series of antiviral agents complexed with human rhinovirus 14. Proc. Natl. Acad. Sci. USA 85:3304-3308.

3. Carrasco, L. 1978. Membrane leakiness after viral infection and a new approach to the development of antiviral agents. Nature (London) 272:694-699.

4. Carrasco, L. 1981. Modification of membrane permeability induced by animal viruses early in infection. Virology 113:623-629.

5. Carrasco, L., and M. Esteban. 1982. Modification of membrane permeability in vaccinia virus-infected cells. Virology 117:62-69.

6. Carrasco, L., M. J. Otero, and J. L. Castrillo. 1989. Modification of membrane permeability by animal viruses. Pharm. Ther. 40:171-212.

7. Coombs, K., and D. T. Brown. 1987. The penetration of animal cells by viruses, p. 5-19. In L. Carrasco (ed.), Mechanisms of viral toxicity in animal cells. CRC Press, Inc., Boca Raton, Fla.

8. Crowell, R. L., and K. Lonberg-Holm (ed.). 1986. Virus attachment and entry into cells. American Society for Microbiology, Washington, D.C.

9. De Sena, J., and B. Mandel. 1977. Studies on the in vitro uncoating of poliovirus. I. Characterization of the modifying reaction. Virology 78:554-566.

10. Diana, G. D., M. J. Otto, and M. A. McKinlay. 1985. Inhibitors of picornavirus uncoating as antiviral agents. Pharm. Ther. 29:287-297.

11. Dimmock, N. J. 1982. Initial stages in infection with animal viruses. J. Gen. Virol. 59:1-22.

12. Eggers, H. J., M. A. Koch, A. Furst, G. D. Daves, J. J. Wilczynski, and K. Folkers. 1970. Rhodanine: a selective inhibitor of the multiplication of echovirus 12. Science 167:294-297.

13. Fernandez-Puentes, C., and L. Carrasco. 1980. Viral infection permeabilizes mammalian cells to proteins. Cell 20:769-775.

14. Fitzgerald, D. J. P., R. Padmanabhan, I. Pastan, and M. C. Willingham. 1983. Adenovirus-induced release of epidermal growth factor and Pseudomonas toxin into the cytosol of KB cells during receptor mediated endocytosis. Cell 32:607-617.

15. Fox, M. P., M. J. Otto, and M. A. McKinlay. 1986. Prevention of rhinovirus and poliovirus uncoating by WIN 51711, a new antiviral drug. Antimicrob. Agents Chemother. 30:110-116.

16. Goldstein, J. L., R. G. W. Anderson, and M. S. Brown. 1979. Coated pits, coated vesicles and receptor mediated endocytosis. Nature (London) 279:679-685.

17. Fricks, C. E., and J. M. Hogle. 1990. Cell-induced conformational change in poliovirus: externalization of the amino terminus of VP1 is responsible for liposome binding. J. Virol. 64:1934-1945.

18. Gonzalez, M. E., M. J. Almela, M. Yacout, and L. Carrasco. 1990. 6-(3,4-Dichlorophenoxy)-3-(ethylthio)-2-pyridincarbonitrile inhibits poliovirus uncoating. Antimicrob. Agents Chemother. 34:1259-1261.

19. Gonzalez, M. E., and L. Carrasco. 1987. Animal viruses promote the entry of polysaccharides with antiviral activity into cells. Biochem. Biophys. Res. Commun. 146:1301-1310.

20. Guttman, N., and D. Baltimore. 1977. A plasma membrane component able to bind and alter virions of poliovirus type 1: studies on cell-free alteration using a simplified assay. Virology 82:25-36.

21. Hoch, D. H., M. RomeroMira, B. E. Ehrlich, A. Finkelstein, B. R. DasGupta, and L. L. Simpson. 1985. Channels formed by botulinum, tetanus, and diphtheria toxins in planar lipid bylayers: relevance to translocation of proteins across membranes. Proc. Natl. Acad. Sci. USA 82:1692-1696.

22. Hoekstra, D., and J. W. Kok. 1989. Entry mechanisms of enveloped viruses. Implications for fusion of intracellular membranes. Biosci. Rep. 9:273-305.

23. Hogle, J. M., M. Chow, and D. J. Filman. 1985. Three dimensional structure of poliovirus at $2.9 \AA$ resolution. Science 229:1358-1365.

24. Ishitsuka, H., Y. T. Ninomiya, C. Ohsawa, M. Fujiu, and Y. Suhara. 1982. Direct and specific inactivation of rhinovirus by chalcone Ro 09-0410. Antimicrob. Agents Chemother. 22:617-621.

25. Kagan, B. L., A. Finkelstein, and M. Colombini. 1981. Diphtheria toxin fragment forms large pores in phospholipid bilayer membranes. Proc. Natl. Acad. Sci. USA 78:4950-4954.

26. Luo, M., G. Vriend, G. Kamer, I. Minor, E. Arnold, M. G. Rossmann, U. Boege, D. G. Scraba, G. M. Duke, and A. C. Palmenberg. 1987. The atomic structure of Mengo virus at $3.0 \AA$ resolution. Science 235:182-191.

27. Pevear, D. C., M. J. Fancher, P. J. Felock, M. G. Rossmann, M. S. Miller, G. Diana, A. M. Treasurywala, M. A. McKinlay, and F. J. Dutko. 1989. Conformational change in the floor of the human rhinovirus canyon blocks adsorption to HeLa cell receptors. J. Virol. 63:2002-2007.

28. Otero, M. J., and L. Carrasco. 1987. Proteins are cointernalized with virion particles during early infection. Virology 160:75-80.

29. Rossmann, M. G. 1989. The structure of antiviral agents that inhibit uncoating when complexed with viral capsids. Antiviral Res. 11:3-14.

30. Rossmann, M. G., E. Arnold, J. W. Erickson, E. A. Frankenberger, J. P. Griffith, H. J. Hecht, J. E. Johnson, G. Kamer, M. Luo, A. G. Mosser, R. R. Rueckert, B. Sherry, and G. Vriend. 1985. Structure of a human common cold virus and functional relationship to other picornaviruses. Nature (London) 317:145153.

31. Rossmann, M. G., and J. E. Johnson. 1989. Icosahedral RNA virus structure. Annu. Rev. Biochem. 58:533-573.

32. Seth, P., M. C. Willingham, and I. Pastan. 1984. Adenovirusdependent increase in cell membrane permeability. J. Biol. Chem. 259:14350-14353.

33. Sim, I. S., and K. G. McCullagh. 1985. Potential targets for selective inhibition of viral replication, p. 15-56. In M. R. Harnden (ed.), Approaches to antiviral agents. McMillan, London.

34. Smith, T. J., M. J. Kremer, M. Luo, G. Vriend, E. Arnold, G. Kamer, M. G. Rossmann, M. A. McKinlay, G. D. Diana, and M. J. Otto. 1986. The site of attachment of human rhinovirus 14 for antiviral agents that inhibit uncoating. Science 233:12331356. 